\title{
Development of a Scale to Measure the Perception and Acceptance of Information Technology (IT) Enabled Comprehensive Farm Advisory Services by Farmers
}

\author{
N. Rajeshwari* and S. S. Dolli \\ Department of Agricultural Extension Education, College of Agriculture, Dharwad, \\ University of Agricultural Sciences, Dharwad, India \\ *Corresponding author
}

\begin{tabular}{l} 
K e y w o r d s \\
Perception, \\
Acceptance, IT \\
enabled farm \\
advisory services, \\
Item analysis, \\
Reliability and \\
Validity \\
\hline Article Info \\
$\begin{array}{l}\text { Accepted: } \\
\text { 22 June } 2020 \\
\text { Available Online: } \\
\text { 10 July } 2020\end{array}$ \\
\hline
\end{tabular}

\section{A B S T R A C T}

A scale was developed to measure the "Perception and Acceptance of Information Technology (IT) Enabled Comprehensive Farm Advisory Services by Farmers". The Likert's summated rating scale was followed in the construction of scale. Based on the review of literature and discussion with the expert's, 66 statements were enlisted. The relevancy rating were sent to 250 scientists and extension specialists working in research institutes of Indian Council of Agriculture Research (ICAR), State Agricultural University and development departments for critical evaluation of statements on a 5 point continuum. Out of 250 judges 100 judges responded in time. Based on their judgment an aggregate of 53 statements were selected by finding the relevancy weightage scores (RWS). Statements having an equal or more RWS of 0.75 and mean relevancy score of 3.00 were selected for the item analysis. In item analysis the selected statements were administered to 40 farmers in non-sample area of Navalgund taluk in Dharwad district of Karnataka state during 2018-2019. Finally a total of 48 statements were selected for the study based on ' $t$ ' values $(>1.75)$ resulted from the item analysis and were included in the final scale. The ' $r$ ' value of the scale was found to be 0.9 , which was significant at one per cent level indicating the high reliability. Hence, the scale developed was found to be reliable and valid. The instrument developed to measure the perception and acceptance of information technology (IT) enabled farm advisory services can be used by the researchers.

\section{Introduction}

Agriculture continues to be the most important sector of Indian economy. research, extension and farmers efforts have all contributed significantly to increase in food production. The total demand for food grains is projected to touch 280 million tonnes by the year 2020-21. Meeting this demand will necessitate a growth rate of nearly 2 per cent per annum in food grain production and agriculture sector need to grow targeted 4 per cent per annum. However the extent of adoption is found to be very low (18-19\%) One of the reasons for wide gap is extension worker to farmer ratio resulting in low access to technical information The gap is still widening this may be because of faulty delivery of extension system. Some of studies of ICT have demonstrated their effectiveness 
in filling the information gap and increased adoption of improved technology. Gandhi et $a l$., (2008) indicated that the Digital Green project increased the adoption of certain agriculture practices seven-fold over a classic extension approaches. Further, 85 per cent of adoption of improved technologies achieved as against 11 per cent of adoption by traditional extension methods. Similarly Krishnareddy and Ankaiah, (2005) reported that deploying e-Sagu prototype increased income of the farmers for the tune of INR. 3075 (63 USD) per ha and also reduced the pesticide usage. Saravanan (2008) reported the cost and time indicators comparing traditional extension system and e-Arik (eagriculture) project sixteen fold and three fold less time were required to the clientele availing, extension system delivering extension services, respectively. He further reported that 3.4 fold economic benefit as compared to the expenditure of deploying eagriculture prototype. Hence, Comprehensive Agribusiness Extension Services (CABES) an IT enabled farm advisory service initiated by UAS, Dharwad in collaboration with Indian Institute of Business Management, Bangalore and Scope NGO is one of the attempts to demonstrate the education on improved technology to farmers. Here an attempt is made to provide comprehensive information on farm management on real time basis to improve adoption, productivity and profitability. Hence, in order to study the effectiveness of IT based farm advisory service and its extent of replication and scalability to meet the long standing gap a scale was developed to know the perception and acceptance of information technology (IT) enabled comprehensive farm advisory services by farmers. According to Udai "Pareek perception is defined as the process of receiving, selecting, organizing, interpreting, checking and reacting to sensory stimuli and data" in the present context the perception on IT based farm advisory services- It is the organization, understanding and interpretation of information technology (IT) enabled Comprehensive Farm Advisory Services by the Farmers. Hence, the present study is proposed to study the effectiveness of IT based farm advisory service and its extent of replication and scalability to meet the long standing gap with the following objectives. Hence, the research was taken with an objective to develop and standardize a scale to measure the perception and acceptance of farmers about information technology (IT) enabled Comprehensive Farm Advisory Services by the Farmers.

\section{Materials and Methods}

The present study was carried out during 2018- 2019. Forty farmers from a non-sample area were personally interviewed. The method suggested by the Likert (1932) in developing summated rating scale was used to construct the perception scale. The details of the procedure followed and standardization of the scale to measure the perception of farmers about information technology (IT) enabled Comprehensive Farm Advisory Services

\section{Collection of items / statements}

About 90 draft statements on the perception and acceptance of farmers about Information Technology enabled farm advisory services were collected based on review of literature, journals, thesis discussion with relevant specialists and researcher's own experience. These statements were carefully edited in the light of 14 criteria suggested by Edword (1969). Thus, 66 statements (Appendix I) were selected for further analysis.

\section{Relevancy weightage test}

All the statements collected may not be relevant equally in measuring the perception and acceptance of farmers about Information 
Technology enabled farm advisory services. Hence, these statements were subjected to scrutiny by an expert panel to determine the relevancy and screening for inclusion in the final scale. For this, the list of scrutinized 66 statements were sent to a panel of 150 experts with request to critically evaluate each statement for its relevancy to measure perception of farmers about Information Technology enabled farm advisory services. The experts comprised scientists of ICAR Research Stations and Institutions, Subject matter specialists in KVKs, Agricultural Extension scientists from State Agricultural Universities, Agricultural Scientists from Directorate of Extension who had knowledge in Information Communication Technology and were involved in field level extension for critical evaluation.

The experts were requested to give their response on a fivepoint continuum viz., Most Relevant, Relevant, Somewhat Relevant, Less Relevant and Not Relevant with scores 5,4,3,2 and 1 respectively for positive statementsand Most Relevant (MR), Relevant (R), Somewhat Relevant(SWR) Less Relevant (LR) and Not Relevant (NR) for appropriateness of each statement with the score of 1,2,3,4 and 5 for negative statements respectively.

Out of 150 experts only 50 responded in a time span of two months. The relevancy score of each item was ascertained by adding the scores on rating scale for all the 50 experts' responses. From the data gathered Relevancy Percentage (RP), Relevancy Weightage (RW) and Mean Relevancy score (MRS) were worked out for all the 66 items/ statements by using the following formulae.

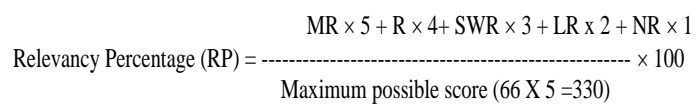

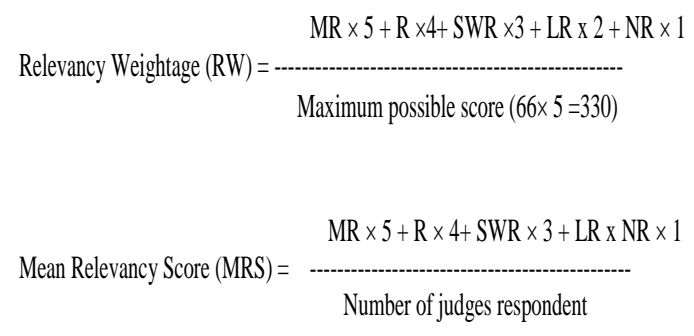

Using these three criteria the statements were screened for their relevancy. Accordingly, statements having relevancy percentage more than relevancy weightage more than 0.75 and mean relevancy score more than 3.00 were considered for final selection of statements. By this process, out of 66 statements, 53 statements have relevancy percentage $>75$, relevancy weightage $>0.75$ and mean relevancy score $>3.00$ and were isolated in the first stage of screening, suitably modified and rewritten as per the comments of experts. Thus finally 53 statements (Table 2) were selected after the relevancy test.

\section{Item analysis}

The selected 53 statements were subjected to item analysis to demarcate the items based on the extent to which they can differentiate the respondents with high perception and low perception ICT enabled farm advisory services. Thus scrutinized statements representing the perception of farmers about IT enabled farm advisory services were administered to 40 respondents from non sample area of Navalgund taluk of Dharwad district of Karnataka state during 2018-2019. The respondents were asked to indicate their degree of agreement or disagreement with each statement on a five point continuum viz., strongly agree, agree, undecided, disagree and strongly disagree with scores of 5, 4, 3, 2 and 1 , respectively and negative statements scores were reversed.

The respondents' responses were recorded and the summated score for the total 
statements of each respondent is obtained. For each respondent the maximum possible score for 53 statements was 265 and the minimum was 53. The scores of the respondents were then arranged in a descending order. The 25 per cent from highest scores (high group) and 25 per cent from lowest scores (low group) were taken for the item analysis. These responses were subjected to item analysis for selection of the items that constitute the final perception and acceptance scale.

The critical ratio i.e., t-value which was a measure of the extent to which a given statement differentiates between the high and low groups of respondents for each statement was calculated by using the following formula

$t=\frac{\bar{X}_{\mathrm{H}}-\bar{X}_{\mathrm{L}}}{\frac{\sqrt{\left(\sum \bar{X}_{\mathrm{H}}{ }^{2}-\frac{\left(\sum \overline{X_{\mathrm{H}}}\right) \rrbracket^{2}}{n}\right) \times\left(\sum \bar{X}_{\mathrm{L}}^{2}-\frac{\left.\left(\sum \bar{X}_{\mathrm{L}}\right)\right]^{2}}{n}\right)}}{n(n-1)}}$

Where,

$\bar{X}_{\mathrm{H}}=$ The mean score on given statement of the high group

$\bar{X}_{\mathrm{L}}=$ The mean score on given statement of the low group

$\sum \mathrm{X}_{\mathrm{H}}^{2}=$ Sum of squares of the individual score on a given statement for high group

$\sum X_{L}^{2}=$ Sum of squares of the individual score on a given statement for low group

$\mathrm{n}=$ Number of respondents in each group

$\mathrm{t}=$ The extent to which a given statement differentiate between the high and low group.

After calculating the t- values for all the items of the attitude scale using the formula, the values of the statements were arranged in descending order from the highest to the lowest and 48 statements were selected from the scale whose values are highest i.e., with tvalues more than 1.75 , for both positive and negative statements.

\section{Selection of Perception and Acceptance Statements for final Scale}

After computing " $t$ " value for all the items, 48 statements with highest " $t$ " value equal to or greater than 1.75 were selected. The thumb rule of rejecting items with ' $t$ ' value less than 1.75 was followed Edwards A L. (1957).

As per the thumb rule selection of items to be retained in the scale, includes the scales with highest discriminating values excluding the scales with poor discriminating ability and questionable validity. Thus, 48 statements were retained for consideration in the final scale based on the following norms:

The ' $\mathrm{t}$ ' value should be more than 1.75

The statement should present a new idea i.e., the idea not overlapping with that expressed other

The statement should be simply worded and brief.

\section{Reliability and validity of Perception and Acceptance Scale}

The scale developed was further standardized by establishing its reliability and validity. "Reliability is the accuracy or precision of measuring instrument" by Ganeshkumar and Ratnakar (2011). To know the reliability of the attitude scale Split-Half method was followed. As validity literally means truthfulness, which refers to "the degree to which a test measures, what it claims to measure" by Kerlinger (1973), content validity was used to measure the validity of the scale. 


\section{Split-Half methodology}

The reliability of the scale was determined by 'Split-Half' method. The split-half method was regarded by many as the best of the methods for measuring reliability.

The 24 selected attitude items were divided into two halves by odd-even method. The two halves were administered separately to 20 farmers in a non-sample area.

The scores were subjected to product moment correlation test in order to find out the reliability of the half-test. The half-test reliability coefficient $(r)$ was 0.90 , which was significant at one per cent level of probability. Further, the reliability coefficient of the whole test was computed using the Spearman-Brown prophecy formula given below.

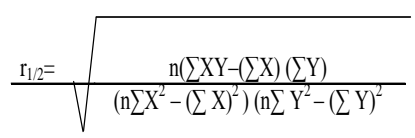

Where,

$\sum \mathrm{X}=$ Sum of the scores of the odd number items

$\sum \mathrm{Y}=$ Sum of the scores of the even numbers items

$\sum X^{2}=$ Sum of the squares of the odd number items

$\sum Y^{2}=$ Sum of the squares of the even number items

$\mathrm{n}=$ Number of respondents

The whole test of the scale was 0.99 , which was highly significant at one per cent level indicating the high reliability of the scale.

\section{Content validity of the attitude scale}

The validity of the scale was established through content validity i.e., the representativeness or sampling adequacy of the content of a measuring instrument. The scale satisfies both these criteria as the clause of universe of statements that could be made about ICT enabled farm advisory services is formulated from the standards and also in consultation with experts who had knowledge about the psychological object. This ensures high content validity of perception and acceptance scale. The scale was constructed in accordance with the steps followed in summated rating scale given by Edward A L. (1957). Therefore, it was assumed that the scores obtained by administering this scale measured nothing other than the perception and acceptance of ICT enabled farm advisory services. While selecting perception statements, due care is taken for obtaining a fair degree of content validity. The calculated " $t$ " value being significant for all the finalized statements of the score indicated that the perception statements of the scale have discriminating values. Hence, it seems reasonable to accept the scale as a valid measure of the perception.

\section{Administration and scoring of perception scale}

The final scale consisted of 48 statements (Table 3). The responses had to be recorded on a five point continuum representing strongly agree, agree, undecided, disagree and strongly disagree with scores of 5, 4, 3, 2, and 1 , respectively for positive statements and vice versa for negative statements. The perception score on this scale ranges from a minimum of 48 to maximum of 240. Higher the perception score indicates the more good perception of farmers about ICT enabled farm advisory services and lesser perception score indicates bad perception of farmers about ICT enabled farm advisory services. 
Table.1 Scale on perception and acceptance of information technology (IT) enabled comprehensive farm advisory services by farmers

Relevancy Percentage, Relevancy Weightage, Mean Relevancy Scores and 't' values

\begin{tabular}{|c|c|c|c|c|c|}
\hline SI.No. & Dimensions for Perception & $\mathbf{R P}$ & RW & MRS & 't' value \\
\hline 1 & Comprehensiveness of content & & & & \\
\hline 1 & $\begin{array}{l}\text { The content given through the } \mathrm{TAB} \text { in } \\
\text { digital form includes all production } \\
\text { practices }\end{array}$ & 86.00 & 00.86 & 4.30 & 3.20 \\
\hline 2 & The content does not cover all topics & 67.20 & 00.67 & 3.11 & NS \\
\hline 3 & $\begin{array}{l}\text { I can get information on any problem I } \\
\text { request in digital form }\end{array}$ & 77.60 & 00.78 & 3.59 & 1.84 \\
\hline 4 & $\begin{array}{l}\text { The content /message includes more on } \\
\text { pest management than other topics }\end{array}$ & 76.8 & 00.77 & 3.56 & 1.90 \\
\hline 5 & $\begin{array}{l}\text { The content updated includes latest } \\
\text { technology of crops }\end{array}$ & 83.2 & 00.83 & 3.85 & 2.82 \\
\hline 6 & $\begin{array}{l}\text { The information received through digital } \\
\text { media is incomplete }\end{array}$ & 65.20 & 00.65 & 3.02 & NS \\
\hline 2 & Field Applicability & & & & \\
\hline 7 & $\begin{array}{l}\text { Information provided through } \mathrm{TAB} \text { has } \\
\text { complete field applicability. }\end{array}$ & 80.80 & 00.81 & 3.74 & 1.85 \\
\hline 8 & $\begin{array}{l}\text { Some of the recommendations cannot be } \\
\text { applied in the field }\end{array}$ & 76.00 & 00.76 & 3.52 & NS \\
\hline 9 & $\begin{array}{l}\text { I can use the advices in the TAB as per } \\
\text { my field conditions }\end{array}$ & 81.20 & 00.81 & 3.76 & 1.78 \\
\hline 10 & $\begin{array}{l}\text { Inputs suggested in the TAB are not } \\
\text { available in market }\end{array}$ & 72.80 & 00.73 & 3.37 & NS \\
\hline 11 & $\begin{array}{l}\text { The best management practices given in } \\
\text { the } \mathrm{TAB} \text { are applicable to my field. }\end{array}$ & 78.80 & 00.79 & 3.65 & 1.76 \\
\hline 12 & $\begin{array}{l}\text { Holistic solutions provided by TAB is } \\
\text { suited to all types of formats }\end{array}$ & 73.20 & 00.73 & 3.39 & NS \\
\hline 3 & Solution for undiagnosed pests & & & & \\
\hline 13 & $\begin{array}{l}\text { The application in the TAB makes the } \\
\text { pest and disease identification and } \\
\text { diagnosis easier }\end{array}$ & 88.00 & 00.88 & 4.07 & 3.20 \\
\hline 14 & $\begin{array}{l}\text { It provides latest and updated information } \\
\text { in pest management }\end{array}$ & 84.80 & 00.85 & 3.93 & 1.82 \\
\hline 15 & $\begin{array}{l}\text { When new pest or disease is observed it is } \\
\text { difficult to get timely solution through the } \\
\text { TAB }\end{array}$ & 76.40 & 00.76 & 3.54 & NS \\
\hline 16 & $\begin{array}{l}\text { Proper identification of pests, pesticides, } \\
\text { chemicals help to reduce injudicious use } \\
\text { of pesticides by farmers }\end{array}$ & 82.00 & 00.82 & 3.80 & 1.76 \\
\hline 17 & $\begin{array}{l}\text { Solutions for undiagnosed pests are } \\
\text { received within } 24 \text { hours }\end{array}$ & 79.20 & 00.79 & 3.67 & 2.98 \\
\hline
\end{tabular}




\begin{tabular}{|c|c|c|c|c|c|}
\hline 18 & $\begin{array}{l}\text { Pest identification is easier with the help } \\
\text { of digital device }\end{array}$ & 82.80 & 00.83 & 3.83 & 3.00 \\
\hline 4 & Timeliness & & & & \\
\hline 19 & $\begin{array}{l}\text { The advice is available at right time on } \\
\text { real time bases. }\end{array}$ & 85.6 & 00.86 & 3.96 & 1.95 \\
\hline 20 & $\begin{array}{l}\text { TAB enabled advice is not available } \\
\text { when requested }\end{array}$ & 70.80 & 00.71 & 3.28 & NS \\
\hline 21 & $\begin{array}{l}\text { Solution provided for pest and disease } \\
\text { identification were timely }\end{array}$ & 86.40 & 00.86 & 4.00 & 1.91 \\
\hline 22 & $\begin{array}{l}\text { The timeliness of the information helped } \\
\text { to reduce crop losses }\end{array}$ & 91.20 & 00.91 & 4.22 & 1.74 \\
\hline 23 & $\begin{array}{l}\text { Using } \mathrm{TAB} \text { we can get any information at } \\
\text { any time }\end{array}$ & 84.00 & 00.84 & 3.89 & 2.02 \\
\hline 24 & $\begin{array}{l}\text { We have to wait for the field staff to get } \\
\text { information from } \mathrm{TAB}\end{array}$ & 69.20 & 00.69 & 3.20 & NS \\
\hline 5 & Accuracy & & & & \\
\hline 25 & $\begin{array}{l}\text { The information includes } \\
\text { recommendations by University and } \\
\text { ICAR }\end{array}$ & 88.80 & 00.89 & 4.11 & 1.81 \\
\hline 26 & $\begin{array}{l}\text { The information provided contradicts } \\
\text { with the information provided by other } \\
\text { sources like seed companies and private } \\
\text { agencies }\end{array}$ & 72.00 & 00.72 & 3.33 & NS \\
\hline 27 & $\begin{array}{l}\text { The recommendations are not specific to } \\
\text { my crop/area }\end{array}$ & 72.00 & 00.72 & 3.33 & NS \\
\hline 28 & $\begin{array}{l}\text { The information provided by } \mathrm{TAB} \text { is } \\
\text { precise and real }\end{array}$ & 82.00 & 00.82 & 3.8 & 1.85 \\
\hline 29 & $\begin{array}{l}\text { The TAB provides information on all } \\
\text { stages of crop growth }\end{array}$ & 84.00 & 00.84 & 3.89 & 3.10 \\
\hline 30 & $\begin{array}{l}\text { All the proportions of inputs and other } \\
\text { recommendations mentioned in the digital } \\
\text { device are correct }\end{array}$ & 79.20 & 00.79 & 3.67 & 2.11 \\
\hline 6 & Speed & & & & \\
\hline 31 & $\begin{array}{l}\text { The information is delivered on the spot } \\
\text { in the printed form }\end{array}$ & 80.00 & 00.80 & 3.72 & 1.90 \\
\hline 32 & $\begin{array}{l}\text { The interactive time between the scientist } \\
\text { and the farmer is short. }\end{array}$ & 82.40 & 00.82 & 3.81 & NS \\
\hline 33 & $\begin{array}{l}\text { Farmer has to wait for the field staff to } \\
\text { get the information }\end{array}$ & 74.40 & 00.74 & 3.44 & NS \\
\hline 34 & Poor connectivity hinders the speed & 82.00 & 00.82 & 3.80 & 3.80 \\
\hline 35 & $\begin{array}{l}\text { The device is not suitable for rural areas } \\
\text { due to connectivity issues }\end{array}$ & 78.40 & 00.78 & 3.63 & 3.00 \\
\hline 36 & $\begin{array}{l}\text { Time is saved as the recommendations } \\
\text { are received then and there }\end{array}$ & 85.20 & 00.85 & 3.94 & 1.84 \\
\hline 7 & Presentation of Audio Visual Content & & & & \\
\hline
\end{tabular}




\begin{tabular}{|c|c|c|c|c|c|}
\hline 37 & $\begin{array}{l}\text { The pictures and videos in the TAB gives } \\
\text { a contrived experience }\end{array}$ & 83.60 & 00.84 & 3.87 & 1.77 \\
\hline 38 & $\begin{array}{l}\text { The visual images help in identifying the } \\
\text { symptoms of insect pest and diseases }\end{array}$ & 89.60 & 00.90 & 4.15 & 2.09 \\
\hline 39 & $\begin{array}{l}\text { Farmer himself can handle the device as it } \\
\text { is guided by pictorial images }\end{array}$ & 84.40 & 00.84 & 3.91 & NS \\
\hline 40 & The pictures are not clear and confusing & 70.40 & 00.70 & 3.26 & 2.60 \\
\hline 41 & $\begin{array}{l}\text { Audio Visual pictures only on some } \\
\text { practices gives clear and complete } \\
\text { information }\end{array}$ & 80.00 & 00.8 & 3.70 & 3.24 \\
\hline 42 & $\begin{array}{l}\text { The pictures shown do not relate to my } \\
\text { crop }\end{array}$ & 69.20 & 00.69 & 3.20 & NS \\
\hline 8 & User Friendly Device & & & & \\
\hline 43 & Programme is user friendly & 84.40 & 00.84 & 3.91 & NS \\
\hline 44 & $\begin{array}{l}\text { The reference pictures shown are clear } \\
\text { and specific }\end{array}$ & 83.30 & 00.83 & 3.85 & 2.13 \\
\hline 45 & $\begin{array}{l}\text { Identification of specimen, pest and } \\
\text { disease is easy because of pictorial } \\
\text { representation. }\end{array}$ & 86.80 & 00.87 & 4.02 & 1.91 \\
\hline 46 & $\begin{array}{l}\text { Language used in the device is simple and } \\
\text { clear }\end{array}$ & 83.60 & 00.84 & 3.87 & 1.99 \\
\hline 47 & $\begin{array}{l}\text { Always an interpreter is needed to } \\
\text { decipher the information }\end{array}$ & 79.20 & 00.79 & 3.67 & 2.82 \\
\hline 48 & $\begin{array}{l}\text { The dosages are given in printed formats } \\
\text { so it is easy to follow }\end{array}$ & 82.00 & 00.82 & 3.80 & 1.85 \\
\hline 9 & Agricultural Input Selection & & & & \\
\hline 49 & $\begin{array}{l}\text { Digital extension service helps in } \\
\text { selection of appropriate inputs. }\end{array}$ & 84.00 & 00.84 & 3.89 & 1.80 \\
\hline 50 & $\begin{array}{l}\text { The information on best management } \\
\text { practices has helped to reduce } \\
\text { indiscriminate use of pesticides and } \\
\text { fertilizers. }\end{array}$ & 88.40 & 00.88 & 4.09 & 1.85 \\
\hline 51 & $\begin{array}{l}\text { The stepwise procedure is given for input } \\
\text { selection and cultivation practices }\end{array}$ & 82.00 & 00.82 & 3.80 & 1.77 \\
\hline 52 & $\begin{array}{l}\text { Many recommended inputs are not } \\
\text { available in regular markets }\end{array}$ & 76.80 & 00.77 & 3.56 & 1.93 \\
\hline 53 & $\begin{array}{l}\text { The input suggestions are relevant to my } \\
\text { area }\end{array}$ & 76.40 & 00.76 & 3.54 & 1.83 \\
\hline 54 & $\begin{array}{l}\text { The pictures shown helps in right input } \\
\text { selection }\end{array}$ & 83.60 & 00.84 & 3.87 & 2.22 \\
\hline 10 & Market Decision & & & & \\
\hline 55 & $\begin{array}{l}\text { The price forecast helps in taking } \\
\text { decision where to sell the produce }\end{array}$ & 89.60 & 00.90 & 4.15 & 1.76 \\
\hline 56 & $\begin{array}{l}\text { We cannot use recommended inputs as } \\
\text { most of them are not available in Raitha }\end{array}$ & 77.20 & 00.77 & 3.57 & NS \\
\hline
\end{tabular}




\begin{tabular}{|c|c|c|c|c|c|}
\hline & Samparka Kendras on subsidy & & & & \\
\hline 57 & $\begin{array}{l}\text { Information about Warehouses is } \\
\text { provided in a comprehensive manner }\end{array}$ & 78.40 & 00.78 & 3.63 & 2.05 \\
\hline 58 & $\begin{array}{l}\text { The information on markets help to } \\
\text { decide which crop to grow }\end{array}$ & 85.20 & 00.85 & 3.94 & 3.10 \\
\hline 59 & $\begin{array}{l}\text { The demand for a particular crop can be } \\
\text { understood }\end{array}$ & 85.20 & 00.85 & 3.94 & 2.24 \\
\hline 60 & $\begin{array}{l}\text { Advisory service includes processing } \\
\text { units and value addition }\end{array}$ & 80.00 & 00.80 & 3.70 & 3.03 \\
\hline 61 & $\begin{array}{l}\text { Information on prices in different markets } \\
\text { help in proper decision }\end{array}$ & 82.00 & 00.82 & 3.80 & 1.78 \\
\hline 11 & Follow up support/assistance & & & & \\
\hline 62 & $\begin{array}{l}\text { Advisory services include information on } \\
\text { various schemes }\end{array}$ & 87.60 & 00.88 & 4.06 & 2.94 \\
\hline 63 & $\begin{array}{l}\text { TAB provides different formats for } \\
\text { applying to crop insurance schemes }\end{array}$ & 83.20 & 00.83 & 3.85 & 2.54 \\
\hline 64 & $\begin{array}{l}\text { It is not of much use because producers } \\
\text { already know about the various schemes }\end{array}$ & 65.20 & 00.65 & 3.02 & NS \\
\hline 65 & $\begin{array}{l}\text { Advisory services do not take } \\
\text { responsibility of co-ordination or linkage }\end{array}$ & 74.80 & 00.75 & 3.46 & NS \\
\hline 66 & $\begin{array}{l}\text { There is no details in the device about the } \\
\text { various schemes }\end{array}$ & 70.80 & 00.71 & 3.28 & NS \\
\hline
\end{tabular}

In conclusion the perception scale developed was found to be reliable and valid. The perception scale developed was administered to 40 registered farmers of non sample area, there were no complications in using the scale, hence it can be concluded that the scale developed was useful in explicitly measuring the perception of farmers towards ICT enabled farm advisory services. Researchers can use the scale in future for measuring the perception of farmers in similar studies.

\section{References}

Dosai, Fahad Owis and Waqar, Muhammed., 2015, Perception of rural people towards information and communication technology (ICT) as influenced by income levels in district Lodhran Pakistan, $14^{\text {th }}$ International Conference,
Paris, $18^{\text {th }}$ Mar., 2015.

Edwards AL. Techniques of attitude scale construction, Vakils. Feffer and Simons Pvt. Ltd., Bombay; 1969.

Edwards AL. Techniques of attitude scale construction. Appleton-century crofts, New York; 1957.

Ganesh Kumar P, Ratnakar P. 2011 A scale to measure farmers' attitude towards ICTbased extension services. Indian Research Journal of Extension Education. Society of Extension Education (SEE), Agra; 2011.

Kerlinger FN. Foundations of behavioral research. Holt, Rinehart and Winston. New York; 1973.

Likert RA. A technique for the measurement of attitude. Arc. Psychology; 1932.

Thurstone, L. L., 1946, Comment American J. Sociol., 52: 39-50. 


\section{How to cite this article:}

Rajeshwari, N. and Dolli, S. S. 2020. Development of a Scale to Measure the Perception and Acceptance of Information Technology (IT) Enabled Comprehensive Farm Advisory Services by Farmers. Int.J.Curr.Microbiol.App.Sci. 9(07): 3299-3308.

doi: https://doi.org/10.20546/ijcmas.2020.907.385 